\title{
THE EFFECT OF Bacillus thuringiensis TOXIN Cry1A.105 AND Cry2Ab2 ON THE SURVIVAL OF THE NON-TARGET PEST, Spodoptera litura
}

\author{
PENGARUH TOKSIN Bacillus thuringiensis Cry1A.105 DAN Cry $2 A b 2$ \\ TERHADAP KELANGSUNGAN HIDUP HAMA BUKAN SASARAN, Spodoptera litura
}

\author{
Kurnia Pratiwi ${ }^{1)}$, Y. Andi Trisyono ${ }^{1)}$, \& Edhi Martono ${ }^{1)}$ \\ ${ }^{1)}$ Department of Plant Pest and Disease, Faculty of Agriculture, Universitas Gadjah Mada \\ Jln. Flora 1, Bulaksumur, Sleman, Yogyakarta 55281 \\ *Corresponding author.E-mail: kurniapratiwi@gmail.com
}

\begin{abstract}
Spodoptera litura is one of the important insect pest of maize besides the notoriously damaging corn borer, Ostrinia furnacalis. S. litura has been the target of various controls including the use of Bacillus thuringiensis (Bt) toxin Cry1A.105 and Cry2Ab2. This study was conducted to evaluate the acute effect of Bt toxin Cry1A.105 and Cry2Ab2 on the growth and development of $S$. litura from larval to adult stages. Two sublethal concentrations were used; 0.1875 and $0.0469 \mathrm{ppm}$ for Cry1A.105, and 0.0008 and $0.0003 \mathrm{ppm}$ for Cry2Ab2. The bioassay using diet dipping was carried out on a CRD with three experiments and five repetitions. The observation was carried out on the mortality and survival rates of $S$. litura. The mortality reached $28 \%$ when the larvae were treated with $0.1875 \mathrm{ppm}$ and $20 \%$ with $0.0469 \mathrm{ppm}$ of Cry 1A.105. The exposed larvae and pupae were smaller than control. Larval and pupal weight were 117.0 and $165.6 \mathrm{~g}$ with $0.1875 \mathrm{ppm}$, while control were 212.9 and $211.2 \mathrm{~g}$. Cry1A.105 also longer the larval stage, larval stage with higher and lower concentration were 24.5 and 22.3 day, while control was 20.5 day. The resulted pupae from larve which exposed by Cry1A.105 were less than control; there were $40 \%$ at concentration $0.1875 \mathrm{ppm}$ and control $61 \%$. The two concentration of Cry $2 \mathrm{Ab} 2$ produced similar mortality of $20 \%$. Similarly, Cry $2 \mathrm{Ab} 2$ affected pupal to adult stages development. The longevity of pupal stage with concentration 0.0003 ppm was 9.5 days, followed by 0.0008 ppm (9.1 days) and control (10.1 days). The adult emerge on the highest concentration was $47.4 \%$ while control only $34.6 \%$. There results showed that both Cry1A.105 and Cry2Ab2 were detrimental to the survival of S. litura which is the non-target insect of transgenic Bt maize.
\end{abstract}

Keywords: Cry1A.105, Cry2Ab2, maize, non-target pest, Spodoptera litura, survival

\section{INTISARI}

Spodoptera litura merupakan salah satu hama penting yang menyerang tanaman jagung, selain Ostrinia furnacalis. Belakangan ini $\mathrm{O}$. furnacalis diketahui telah menjadi target dari berbagai macam cara pengendalian termasuk penggunaan toksin Bacillus thuringiensis (Bt) Cry1A.105 dan Cry2Ab2. Penelitian ini dilakukan untuk mengetahui efek akut toksin Bt Cry1A.105 dan Cry2Ab2 terhadap pertumbuhan dan perkembangan S. litura dari larva sampai imago. Dua konsentrasi subletal yang akan digunakan adalah; 0,1875 dan 0,0469 ppm untuk Cry1A.105, dan 0,0008 dan 0,0003 ppm untuk Cry2Ab2. Pengujian dilakukan dengan menggunakan metode celup pakan dan Rancangan Acak Legkap dengan tiga perlakuan dan lima ulangan. Pengamatan dilakukan terhadap mortalitas dan kelangsungan hidup S. litura. Mortalitas mencapai $28 \%$ pada larva yang dipaparkan dengan 0,1875 ppm dan 20\% dengan 0,0469 ppm Cry 1A.105. Larva dan pupa yang terkena toksin berukuran lebih kecil. Berat larva dan pupa yang terpapar toksin dengan konsentrasi 0,1875 ppm, masing - masing 117,0 dan 165,6 g, sedangkan kontrol masing-masing 212,9 dan 211,2 g. Cryl A.105 juga dapat memperpanjang stadia larva. Lama stadia larva dengan konsentrasi tertinggi dan terendah adalah 24,5 dan 22,3 hari, sedangkan kontrol 20,5 hari. Jumlah pupa yang berhasil terbentuk dari larva yang terpapar toxin CrylA.105 lebih sedikit dibandingkan dengan kontrol; pada konsentrasi 0,1875 ppm sebesar 40\%, sedangkan kontrol sebesar 61\%. Kedua konsentrasi dari toksin Bt Cry2Ab2 menyebabkan mortalitas yang sama yaitu 20\%. Cry2Ab2 juga berpengaruh terhadap lama stadia pupa dan tingkat keberhasilan pembentukan imago. Lama stadia pupa dengan konsentrasi 0,0003 ppm adalah 9,5 hari, diikuti dengan konsentrasi 0,0008 ppm (9,1 hari) dan kontrol (10,1 hari). Jumlah imago terbanyak terdapat pada perlakuan dengan konsentrasi 0,0008 ppm sebesar 47,4\% sedangkan pada kontrol hanya 34,6\%. Hal ini menunjukkan bahwa toksin Bt Cry1A. 105 dan Cry2Ab2 juga berpengaruh terhadap kelangsungan hidup S. litura yang merupakan serangga bukan sasaran dari tanaman jagung transgenik Bt.

Kata kunci: Cry1A.105, Cry2Ab2, hama bukan sasaran, jagung, kelangsungan hidup, Spodoptera litura 


\section{INTRODUCTION}

Maize is one of the most important crop in Indonesia. It is used as foods, feeds, and raw materials for many industries. Two regions in Indonesia, the islands of Madura and Nusa Tenggara, are especially known to grow maize for livestock feeds (Respati et al., 2013). The demand of maize in Indonesia is expected to increase along with the growth of the country's population, however, maize production is often insufficient that this commodity is continued to be imported every year. The production of dry grain in 2013 amounted of 18.51 million tons decreased to $4.5 \%$ from 2012 (BPS, 2014a). The reduction of national maize production is also raised the import rate. Indonesia imported maize for 2.9 million tons in 2013, whereas in 2014 the number was expected to achieve 3.6 million tons (BPS, 2014b). The dependence on maize import will create the negative impact to the domestic maize production. If the problem continues, the country's food security and the livestock businesses sustainability would be threatened.

The reduction of maize production in Indonesia is influenced by several factors, one of them is pests and diseases. There are a number of pests recorded on maize such as stem borer (Ostrinia furnacalis), ear borer (Helicoverpa armigera), seed flies (Atherigona sp.), Aphids sp., grasshopper (Valanga nigricornis), army worm (Spodoptera litura), and grubs (Lachnosterna sp. and Holotrichia sp.) (Kalshoven, 1981). S. litura is the main pest on a number of agricultural crops in Southeast Asia and spread out in the entire Africa and Europe, however it is considered less importance than $O$. furnacalis on maize. The percentage of maize lost in yield by $O$. furnacalis ranged between $20-80 \%$ (Nonci, 2004), while the attack of $S$. litura amounted to $0-57 \%$ (Halim et al., 2014). S. litura is a polyphagous insect, which infest a number of crops such as tomato, cotton, tobacco, rice, cacao, orange, sweet potato, peanut, soybean, potato, cabbage, and maize (Kalshoven, 1981).

Pest control on maize is mainly targeting $O$. furnacalis as the main source of yield loss. Many control methods have been employed to keep this pest on check including biological control and synthetic chemical pestisides (Subiadi et al., 2014). One of the currently developed biological control method is the use of Bacilus thuringiensis (Bt), either conventionally by direct spraying or inserted within the transgenic maize crops throught genetically modification procedure (George \& Crickmore, 2012). There are many toxins that have been used to create transgenic maize such as Cry1A.105, Cry1Ab, Cry2Ab2, Cry34Ab1, Cry35Ab1, Cry3Bb, Cry3Bb1, and Cry1F
(Roh et al., 2007). Two of them, the Cry1A.105 and Cry2Ab2 are expressed in the transgenic maize MON 89034, which has been developed in America since 2009. The target insect pests of MON 89034 are $H$. zea, O. nubilalis, O. furnacalis, S. frugiperda, Diatraea saccharalis, and D. grandiosella (PSA, 2015). Bt toxins can also be employed to control $S$. litura. Cry $1 \mathrm{C}$ is expressed in tobacco and is proven to increase the mortality of $S$. litura larvae from $76.9 \%$ to $100 \%$ within 72 hours after treatment (Lin et al., 2003). Furthermore, Cry1C, Cry1Ac, and $\mathrm{Cry} 2 \mathrm{Ab}$ which are expressed in cotton are also demonstrated to influence the survival of S. litura by deterring the growth of the late instar larvae (Naik et al., 2013).

Bt toxin is known to have high specificity to their target pest up to the species level (Ruut et.al., 2001). However, maize productivity may decline because of non-target pests which increase in number after the reduction of the main pest population. On the other hand, there is also report which stated the impact of Bt toxin on the non-target pest (BRAD, 2009). As $S$. litura and $O$. furnacalis belong to the same order, the Lepidoptera, therefore, the use of Cry1A.105 and Cry2Ab2 targeting O. furnacalis may also affect S.litura. The impact of both toxins on this army worm has yet to be determined by the release of transgenic maize in Indonesia. This study was arranged to determine the acute effects of $\mathrm{Bt}$ toxin Cry1A.105 and Cry2Ab2 on the development of $S$. litura larvae to its adult stage.

\section{MATERIALS AND METHODS}

\section{The Collection and Rearing of Spodoptera litura}

The starting population of S. litura was collected from cabbage plantation in Muntilan, Central Java. Thirty larvae were collected and reared in plastic jars (diameter $14 \mathrm{~cm}$, height $6 \mathrm{~cm}$ ), fed with organic pakcoy (Brassica rapa) leaves. The leaves were obtained from the nearby supermarket, and were cleaned before given to the insects. The larval containing jars were then sealed with a gauze. The diet was replaced every two days until the larvae pupating. The pupae were left in the jar until they molted to adults. The adults were paired and kept in the separate jar to mate. The jar was layered with a paper for eggs laying and were given the $10 \%$ honey solution. The resulted egss were collected and transferred to plastic vial (diameter $3.5 \mathrm{~cm}$, height $4.5 \mathrm{~cm}$ ). The jars were labelled with the eggs laying date. The third generation of firstinstar (neonate) were used in the treatment. 


\section{The Artificial Diet}

Bioassays were carried out with the artificial diet. The diet recipe has been used for mass rearing of $O$. furnacalis in the Toxicology Laboratory of Universitas Gadjah Mada since 2009, and can also be used for S. litura larvae. The diet was consisted of red beans, wheat bran, yeast powder (fermipan), ascorbic acid, sorbic acid, vitamin mix, casein, tetracycline, agar, and distilled water. The beans were soaked in water for \pm 24 hours, and then finely blended. Others ingredients (except agar) were added into the blender and mixed thoroughly. The agar was dissolved in distilled water. The blended ingredients were poured onto the agar and mixed completely. The mixture was then poured into the plastic trays and allowed to cool. The diet were finally stored in the refrigerator $\left(5^{\circ} \mathrm{C}\right)$ until used.

\section{The Bioassays}

Determination of sublethal concentrations. The bioassay was preceeded by preparing the toxin solutions. Two Bt toxins namely Cry1A.105 and Cry2Ab2 (Monsanto, St Louis, Missouri, USA) were employed in this study. The original concentration of the stock toxins of Cry1A.105 and Cry2Ab2 were 96 and 31 ppm respectively. Half of these concentrations or 48 and $15.5 \mathrm{ppm}$ were used in this bioassay, based on the previous assay conducted for $O$. furnacalis (Trisyono, 2015, unpublished). One $\mathrm{ml}$ of each toxins was mixed with $9 \mathrm{ml}$ of buffer. Cry1A.105 was dissolved in the buffer containing $25 \mathrm{mM}$ CAPS, pH 10.3, 1 mM benzamidine-HCl, 0.1 mM EDTA, and $0.2 \mathrm{mM}$ DDT, while Cry2Ab2 was dissolved in the buffer containg $50 \mathrm{mM}$ CAPS, $\mathrm{pH} 11$, and $2 \mathrm{mM}$ DDT. Ten $\mathrm{ml}$ of the two toxins were then diluted in 10 series of concentration to obtain the working solutions for bioassay. The working solutions for Cry1A.105 ranged from 48 to $0.0938 \mathrm{ppm}$, while for Cry2Ab2 their range was from 15.5 to $0.0008 \mathrm{ppm}$. However, when these solutions were used on the first instar of $S$. litura, only Cry2Ab2 that resulted in more than $50 \%$ mortality, while Cry $1 \mathrm{~A} .105$ only gave less than $50 \%$ mortality (Attachment 1). Therefore, we doubled the highest concentration of Cry1A.105 from 48 to $96 \mathrm{ppm}$. Thus, the series of concentrations for Cry1A.105 ranged from 96 to $0.1875 \mathrm{ppm}$ (96, $48,24,12,6,3,1.5,0.75,0.375$, and $0.1875 \mathrm{ppm}$ ), while the same range of concentrations of 15.5 to $0.0008 \mathrm{ppm}(15.5,5.1667,1.7222,0.5741,0.1914$, $0.0638,0.0213,0.0071,0.0024,0.0008 \mathrm{ppm}$ ) of $\mathrm{Cry} 2 \mathrm{Ab} 2$ previously used for $O$. furnacalis were again utilized in this study. Increasing concentrations did not result a significant increase in mortality, therefore four out of the ten series of concentrations were employed to determine the sublethal concentratios (Table 1). These four concentrations were; the highest, two of the middle, and the lowest concentrations. The series concentration of Cry1A.105 used were $96,6,3$, and $0.1875 \mathrm{ppm}$, while for Cry2Ab2 the series were 15.5, 0.1914, 0.0638, and $0.0008 \mathrm{ppm}$.

The toxins were administered through feed dipping (FD) method. The artificial diet was cut, weighed \pm $1 \mathrm{~g}$, and then dipped for $10 \mathrm{sec}$ in toxin solution. The larvae on the control treatment were fed with the same amount of artificial diet previously dipped in distilled water. The diets were left to dry on a piece of filter paper for \pm 15 minutes, before each of them was placed inside the test vials (diameter $=3.5 \mathrm{~cm}$, hight $=4.5 \mathrm{~cm}$ ). Ten first instar (neonate) were added to each vials. The vials were then properly labelled.

The larval mortality were observed on the third day and seventh day after treatment (DAT). Larvae which survived their third day were removed individually to the new vial equipped with a cube of toxin free diet. Each experiments was repeated five times. The mortality rates observed on 3 and 7 DAT were then used as the basis for the sublethal effect bioassay to the growth and development of S. litura larvae.

Table 1. The mortality of early molted larvae of Spodoptera litura treated with Bacillus thuringiensis toxins Cry1A.105 and Cry2Ab2 on 7 day after treatment

\begin{tabular}{lccc}
\hline Toxin & Concentration $(\mathrm{ppm})$ & No. of neonate larvae & Mortality $(\%)$ \\
\hline Cry1A.105 & 96 & 50 & 72 \\
& 6 & 50 & 34 \\
& 3 & 50 & 36 \\
& 0.1875 & 50 & 40 \\
Cry2Ab2 & 0 & 50 & 8 \\
& 15.5 & 50 & 52 \\
& 0.191 & 50 & 28 \\
& 0.064 & 50 & 36 \\
& 0.0008 & 50 & 46 \\
& 0 & 50 & 4 \\
\hline
\end{tabular}


Effects of Cry1A.105 and Cry2Ab2. The lowest concentration and one fourth of the lowest concentration were used in this bioassay. Therefore, the series of toxin solutions used were 0.1875 and $0.0469 \mathrm{ppm}$ for Cry1A.105 and 0.0008 and 0.0003 ppm for Cry2Ab2. In this bioassay, FD method was again employed under CRD. Each experiment was consisted of five replicates, while each replicate employed ten first instar. The larva was placed individually in each vial. A cube of toxin treated diet $(1 \mathrm{~g})$ was given to the larva and replaced with the toxin-free cube whenever it was finished.

The observation was conducted every day until the larvae reached the adult stage. The observed parameters were covering the mortality rate on 3 and 7 DAT, the weight of larvae and pupae, and the longevity of larvae and pupae. The larval weight was measured on 7 and 14 DAT, while the pupae were weighted on the second day after pupation. The weights were measured using electronic analitical scale (SHIMADZU AW 120 max $120 \mathrm{~g} \mathrm{~d}=0.1 \mathrm{mg}$ ). Larval stage was counted from the first DAT until they pupated, while pupal stage was counted as the time needed from pupation to adult eclosion. The resulted data were analysed using ANOVA. Significant difference among the experiment were analyzed with Duncan's Multiple Range Test at 5\% level using SAS 9.1.3 Portable software.

\section{RESULTS AND DISCCUSSION}

\section{Determination of Sublethal Concentration}

The mortality rate of $S$. litura larvae on 7 DAT treated with both Cry1A.105 and Cry2Ab2 were not very different from each other (Table 1). The mortality due to different concentration was not prominent although the difference between the lowest and the highest concentration reached $512 \times$ for Cry $1 \mathrm{~A} .105$ and $19.683 \times$ for Cry2Ab2. Therefore, the lowest concentration $(0.1875 \mathrm{ppm})$ and one fourth of the lowest concentration (0.0469) were chosen as the working concentrations for the rest of the studies. On Cry1A.105 the testing concentration was $0.1875 \mathrm{ppm}$ and $0.0469 \mathrm{ppm}$, while on Cry2ab2 the concentrations of $0.0008 \mathrm{ppm}$ and $0.0003 \mathrm{ppm}$ were selected. These concentrations were then employed to test the effect of both Cry1A.105 and Cry2Ab2 on the survival of $S$. litura.

\section{The Effect of Bt toxin Cry1A.105 on Spodoptera litura}

Bt Cry1A.105 caused the mortality, reduxed weight gain, and prolong the length of larval stadium (Table 2). Larval mortality between the toxins treated and the control treatments was significantly different on both 3 and 7 DAT, and slightly different from one concentration of the treatment to another. On 3 DAT no mortality was observed on control treatment, while 12 and $16 \%$ of mortality were found on the concentration of 0.0469 and 0.1875 ppm respectively. Similarly, on 7 DAT only $2 \%$ mortality was observed in control treatment, while 20 and $28 \%$ of mortality was seen on the concentration of 0.0469 and 0.1875 ppm, respectively. Larval weight on 7 DAT was not significantly different among all concentration including control (ranging from 3.2 to $5.1 \mathrm{~g}$ ), however on the 14 DAT the highest concentration of 0.1875 ppm was resulted in the significantly lighter larvae $(117.0 \mathrm{~g})$ than control $(212.9 \mathrm{~g})$, but not significantly different to the larvae treated with lower concentration of $0.0469 \mathrm{ppm}(141.6 \mathrm{~g})$. The length of the larval stadium was slightly longer on the Bt Cry1A.105 treated larvae with 22.3 and 24.5 days on the lower and higher concentration respectively, compared to the control with 20.5 days. The percentage of pupation was higher on the control treatment (72\%), compared to the toxins treated larvae with 36 and $30 \%$ for 0.0469 and $0.1875 \mathrm{ppm}$ respectively.

The weight of pupae and the percentage of pupae that reached the adult stage was slightly different between the toxins treated and the control, but similar among the toxins treated treatments (Table 2). The weight of male pupae on control treatment (211.2 g) was significantly higher than the pupae resulted from the treated larvae with the concentration of $0.1875 \mathrm{ppm}$ (165.6 g), however they were similar to the pupae resulted from the larvae treated with the lower concentration of $0.0469 \mathrm{ppm}(198.1 \mathrm{~g})$. On the contrary, the weight of female pupae on control treatment $(246.6 \mathrm{~g})$ was similar to the pupae resulted from the larvae treated with the concentration of $0.1875 \mathrm{ppm}(227.9 \mathrm{~g})$, but significantly heavier to the pupae resulted from the larvae treated with lower concentration of $0.0469 \mathrm{ppm}(205.4 \mathrm{~g})$. The percentage of pupae that reached the adult stage was higher $(61 \%)$ on control treatment compared to both the toxins treated treatments, with the percentage of these two were almost similar with 33.3 to $40 \%$ on the lower and higher concentration respectively. The length of pupal stadium was not different from each treatment, which was ranged from 9.3 to 10.2 days.

\section{The Effect of Bt toxin Cry2Ab2 on Spodoptera litura}

Similar to Cry1A.105, Cry2Ab2 was also caused larval mortality (Table 3 ). The mortality of the toxins' treated larvae was higher on both 3 and 7 DAT to the control, but not to each other. On 3 DAT no mortality was observed on control treatment, but 8 to $10 \%$ mortality were found on the concentration of 0.0003 
Table 2. Mortality, growth, and development of newly hatched larvae of Spodoptera litura treated with Bacillus thuringiensis toxins Cry1A.105

\begin{tabular}{llccc}
\hline Stage & Parameters of observation & \multicolumn{3}{c}{ Concentration (ppm) } \\
\cline { 2 - 5 } & & 0 & 0.0469 & 0.1875 \\
\hline First instar & No. larvae & 50 & 50 & 50 \\
& Mortality 3 DAT & 0 & 12 & 16 \\
& Mortality 7 DAT & 2 & 20 & 28 \\
& Weight (mg) 7 DAT & $4.3 \mathrm{a}$ & $5.1 \mathrm{a}$ & $3.2 \mathrm{a}$ \\
& Weight (mg) 14 DAT & $212.9 \mathrm{a}$ & $141.6 \mathrm{ab}$ & $117.0 \mathrm{~b}$ \\
& Larval stage (day) & $20.5 \mathrm{~b}$ & $22.3 \mathrm{ab}$ & $24.5 \mathrm{a}$ \\
Pupae & 72 & 36 & 30 \\
& Larvae $\rightarrow$ pupae (\%) & $211.2 \mathrm{a}$ & $198.1 \mathrm{ab}$ & $165.6 \mathrm{~b}$ \\
& Weight o (mg) & $246.6 \mathrm{a}$ & $205.4 \mathrm{~b}$ & $227.9 \mathrm{ab}$ \\
& Weight क (mg) & $10.2 \mathrm{a}$ & $9.3 \mathrm{a}$ & $9.5 \mathrm{a}$ \\
& Pupal stage (day) & 61.1 & 33.3 & 40 \\
\hline
\end{tabular}

DAT (day after treatment); numbers followed by the same letter for each parameters in the same rows are not significantly different on 5\% level according to Duncan's Multiple Range Test.

Table 3. Mortality, growth, and development of newly hatched larvae Spodoptera litura treated with Bacillus thuringiensis toxin Cry2 Ab2

\begin{tabular}{llccc}
\hline Stage & Parameters of observation & \multicolumn{3}{c}{ Concentration (ppm) } \\
\cline { 2 - 5 } & & 0 & 0.0003 & 0.0008 \\
\hline \multirow{2}{*}{ First instar } & No. larvae & 50 & 50 & 50 \\
& Mortality 3 DAT & 0 & 8 & 10 \\
& Mortality 7 DAT & 4 & 20 & 20 \\
& Weight (mg) 7 DAT & $3.0 \mathrm{a}$ & $3.3 \mathrm{a}$ & $3.4 \mathrm{a}$ \\
& Weight (mg) 14 DAT & $158.5 \mathrm{a}$ & $179.5 \mathrm{a}$ & $121.0 \mathrm{~b}$ \\
& Larval stage (day) & $23.6 \mathrm{a}$ & $22.2 \mathrm{a}$ & $21.8 \mathrm{a}$ \\
Pupae & 52 & 32 & 38 \\
& Larvae $\rightarrow$ pupae (\%) & $198.5 \mathrm{a}$ & $188.0 \mathrm{a}$ & $181.7 \mathrm{a}$ \\
& Weight Oे (mg) & $237.1 \mathrm{a}$ & $199.9 \mathrm{a}$ & $197.1 \mathrm{a}$ \\
& Weight क (mg) & $10.1 \mathrm{a}$ & $9.5 \mathrm{ab}$ & $9.1 \mathrm{~b}$ \\
& Pupal stage (day) & 34.6 & 43.8 & 47.4 \\
\hline
\end{tabular}

DAT (day after treatment); numbers followed by the same letter for each parameters in the same rows are not significantly different on $5 \%$ level according to Duncan's Multiple Range Test.

and 0.0008 ppm respectively. Similarly, on 7 DAT only $4 \%$ mortality was observed in control treatment, while $20 \%$ mortality was seen on both toxins concentrations. Larval weight on 7 DAT was not significantly different among all concentration and control (ranging from 3.0 to $4.3 \mathrm{~g}$ ). However, on the 14 DAT while on the higher concentration of 0.0008 ppm was significantly lesser in weight $(121.0 \mathrm{mg})$ than both the $0.0003 \mathrm{ppm}(179.5 \mathrm{ppm})$ concentration and to the control (158.5 ppm). The length of the larval stadium was not different from each other treatments. The percentage of pupation was also higher on the control treatment (52\%), compared to the toxins treated larvae with 32 and $38 \%$ for 0.0003 and $0.0008 \mathrm{ppm}$ respectively.

The weight of pupae and the percentage of pupae that reached the adult stage not different between the toxins treated and the control (Table 2). The weight of male pupae on control treatment $(198.5 \mathrm{mg}$ ) was not different from the pupae resulted from the treated larvae with the concentration of $0.0008 \mathrm{ppm}$ (188.0 $\mathrm{mg}$ ) and to those resulted from the larvae treated with the higher concentration of $0.0008 \mathrm{ppm}(181.7 \mathrm{mg})$. The weight of female pupae in overal was higher than that of male, but also not significantly different in all treatments. On control treatment it was 237.1 $\mathrm{mg}$, while on the lower and higher concentrations was 199.9 and $197.1 \mathrm{mg}$ respectively. The percentage of pupae that reached the adult stage on control was surprisingly a little bit lower (34.6\%) compared to both the toxins treated treatments with 43.8 and $47.4 \%$ on the lower and higher concentration respectively. The length of pupal stadium was not different from each treatment, which was ranged from 9.1 to 10.1 days. 
Bt toxin Cry1A.105 and Cry2Ab2 caused variable rate of mortality on S. litura larvae (Table 2 and 3). Cry1A.105 was able to kill 12 to $16 \%$ of larvae on 3 DAT which rose around $1.7 \times$ on 7 DAT or 20 to $28 \%$. The higher concentration of $0.1875 \mathrm{ppm}$ gave a slight but not significantly higher mortality than the $0.0469 \mathrm{ppm}$. Cry2Ab2 performed much better than Cry1A.105, where with the concentrations that were $512 \times$ lower, both concentrations had killed $8-10 \%$ of larvae on 3 DAT, which was multiplied to $2-2.5 \times$ on 7 DAT to $20 \%$. These results showed that Cry2Ab2 was better than Cry1A.105. This result was different from those on $O$. furnacalis and $S$. frugiperda where both toxins produced similar mortality rate of $100 \%$ and more than $95 \%$ respectively, or on D. grandiosella where Cry $2 \mathrm{Ab} 2$ resulted in $95 \%$ mortality while Cry1A.105 caused 90-95\% mortality (BRAD, 2009).

The similarity of the results between the two toxins might be caused by various factors. One of them might be the non-target nature of S. litura. Ruut et al. (2001) and George \& Crickmore (2012) found that the host-specific nature of $\mathrm{Bt}$ toxins, might induce the production of different toxins crystal, which might not be suitable for the non-target pests. The selectivity of $\mathrm{Bt}$ toxin is determined by toxin structure and other factors on the body of the target insects. The binding process of the toxin onto the receptor in the midgut can only be successful whenever they are compatible to each other (Gill, 1995).

The administration of Bt toxin Cry1A.105 and Cry2Ab2 generated different effects on $S$. litura larval and pupal weights (Table 2, 3). Cry1A.105 reduced $S$. litura larval and pupal weight, while Cry $2 \mathrm{Ab} 2$ did not. The larval weight on 3 DAT on the two toxin treatments were not different to control and to each other. However, on 14 DAT the higher concentration of Cry1A.105 (0.1875 ppm) significantly reduced larval weight compared to the control, but there was no significant different between the lower concentration of $0.0469 \mathrm{ppm}$ to the control. Similarly, Cry1A.105 reduced pupal weight significantly, but no notable reduction was observed on the pupae resulted from the larvae treated with Cry2Ab2. These differences might be caused by the different amount of toxins being given, where Cry1A.105 concentrations were much higher than Cry2Ab2. According to Tampubulon et al. (2013), the appetite of S. litura larvae infected by $\mathrm{Bt}$ are reduced and they even ceased to eat, which further reduces larval weight and slowing down their movement.

The longevity of larvae and pupae of S. litura were influenced by different Bt toxins (Table 2, 3). Cry1A.105 prolonged the longevity of $S$. litura larval stage but did not affect the longevity of pupal stage, while Cry2Ab2 did not prolong the longevity of larval stage but that of pupal stage. Furthermore, both Cry1A.105 and Cry2Ab2 decreased the number of larvae that successfully molted to pupae (Table 2, 3). On both concentrations of Cry1A.105 the number of pupae were reduced to 0.4 to 0.48 of the control, while on Cry2Ab2 it was reduced to 0.7 to 0.6 of the control. Similarly, the number of successfully molted adults on Cry1A. 105 were 0.54 to $0.65 \times$ of the control. However, this number on the control treatment of Cry $2 \mathrm{Ab} 2$ was less than that on the toxins treated insects by 0.21 to 0.27 . In general, these results were consistent with the findings of Bortolotto et al. (2015) with toxin Cry 1F and Cry1F + Cry1A.105 + Cry2Ab2 can reduce larval growth of $S$. eridania, although this larva was not their insect target. According to Puspita (2015) Cry1A.105 sublethal concentration can decrease the rate of growth and delay the development of $O$. furnacalis larvae into the pupal and adult stages. Similarly, sublethal concentration of Cry2Ab2 also reduce the development of $O$. furnacalis larvae, cause larval mortality, decrease pupal weight, adults' fertility, and eggs viability. Moreover, larvae which survive to adult stage will produce male adult (Triyani, 2015).

The affect of Bt toxins were different. Even for target species from different countries or regions, sensitivities to expressed toxins vary widely. It cannot be expected that the same species-specific and even population-specific sensitivity to $\mathrm{Bt}$ toxins will apply between different environments and across continents. Local non target species like butterflies of conservation concern and heritage value may therefore be at risk (Bøhn et al., 2010). Monsato conducted extensive studies testing the Cry1A.105 and Cry1A.105 proteins for activity against a range of both target and non target insect species, the results also show that both the Cry1A.105 and Cry2Ab2 proteins are highly specific in insecticidal activity against lepidopteran insects and have little activity against non-lepidopteran insects (PSA, 2015).

\section{CONCLUSION}

Bt toxin Cry1A.105 and Cry2Ab2 targeting $O$. furnacalis could affect the non target $S$. litura survival. The administering Bt toxin Cry1A.105 and Cry2Ab2 on sublethal concentration produced different negative effect on the survival of $S$. litura in laboratory condition. Higher concentration of Bt toxin CrylA.105 administered to S. litura larval diet was given higher mortality, lowered larval and pupal weight, prolonged larval stage and reduced the number of the resulted pupae. 
However, higher concentration of Bt toxin Cry2Ab2 given to $S$. litura increased their larval mortality and prolonged pupal stage.

\section{ACKNOWLEDGEMENT}

This study was partially supported by DIKTI. We thank to PT Branita Sandhini for providing the Bt toxins. Special thank to Dr. Susi Melina conscientious comments in the early draft and reviewers for the comments to improve the article.

\section{LITERATURE CITED}

Agrofarm. 2014. Lampaui Rekor Tertinggi Impor Jagung Capai 3,6 Juta Ton. Majalah Agrofarm. Sabtu, 6 September 2014. http://www.agrofarm.co.id, modified 21/12/14

Biopesticide Registration Action Document (BRAD). 2009. Bacillus thuringiensis Cry1 A.105 and Cry2Ab2 Insecticidal Proteins and the Genetic Material Necessary for Their Production in Corn. http://www.epa.gov/ oppbppd1/biopesticides/pips/mon-89034-brad.pdf, modified 10/1/15.

Bortolotto, O.C., A.F. Buenob, A.P. Queiroz, G.F. Silva, \& G.C. Barbosa. 2015. Larval Development of Spodoptera eridania (Cramer) Fed on Leaves of Bt Maize Expressing Cry1F and Cry1F + Cry1A.105 + Cry2Ab2 Proteins and its Non-Bt Isoline. Revista Brasileira de Entomologia 59: 7-11.

Badan Pusat Statistik (BPS). 2014a. Perkembangan Ekspor dan Impor Indonesia Oktober 2014. Berita Resmi Statistik. No. 87/12/Th. XVI. http://www.bps.go. id, modified 21/12/14.

Badan Pusat Statistik (BPS). 2014b. Produksi Padi, Jagung, dan Kedelai. Badan Pusat Statistik. No. 50/07/Th. XVII. http://www.bps.go.id, modified $21 / 12 / 14$

Bøhn, T., A. Myhr, D. Quist, T. Traavik, \& O. Wikmark. 2010. Impact Assessment of Maize Hybrid MON 89034 xNK603 from Monsanto and Dow AgroSciences (EFSA/GMO/NL/2009/72). GenØk - Centre for Biosafety. http://genok.no/wp-content/uploads/ 2013/ 04/genok_raad_jan2010_h721.pdf, modified 10/3/14.

George, Z., \& N. Crickmore. 2012. Bacillus thuringiensis Applications in Agriculture. Department of Biochemistry, School of Life Sciences, University of Sussex, Falmer. http://www.springer.com/cda/content/document/ cda/download/document/9789400730205-c1.pdf, modified 30/8/15.

Gill, S.S. 1995. Mechanism of Action Bacillus thuringiensis Toxins. Mem Ins Oswaldo Cruz, Rio de Janeiro 90: 69-74.

Halim \& A.M. Kandari. 2012. Pemanfaatan Pangkasan Daun Gulma untuk Memodifikasi Iklim Mikro dalam Pembentukan Pupa Spodoptera Litura pada Tanaman Jagung. Agriplus 22: 170-173.

Kalshoven, L.G.E. 1981. Pest of Crops in Indonesia. Has been revised and translated by P.A.V and der Lann. P T Ichtiar Baru, Van Hoeve, Jakarta. 701 p.

Lin, C.H., Y.Y. Chen, C.C. Tzeng, H.S. Tsay, \& L.J. Chen. 2003. Expression of a Bacillus thuringiensis cry $1 \mathrm{C}$ Gene In Plastid Confers High Insecticidal Efficacy against Tobacco Cutworm - a Spodoptera Insect. Botanical Studies 44: 199-210.

Naik, V.C., N.V. Prasad, G.R. Rao. 2013. Effect of Bt Cotton On Survival and Development of Tobacco Caterpillar, Spodoptera litura (Fabricius) on Different Events ff Bt Hybrids. Academic Journal 8: 5538-5549.

Nonci, N. 2004. Biologi dan Musuh Alami Penggerek Batang Ostrinia furnacalis Guenee (Lepidoptera: Pyralidae) Pada Tanaman Jagung. Jurnal Litbang Pertanian 23: 8-14.

Product Safety Assessment (PSA). 2015. POWERCORE ${ }^{\mathrm{TM}}$.The Dow Chemical Company. http://msdssearch. dow.com, modified 20/12/15.

Puspita, F.N.D. 2015. Efek Kronis Toksin Bacillus thuringiensis CrylA.105 terhadap Pertumbuhan dan Perkembangan Ostrinia furnacalis. Skripsi. Universitas Gadjah Mada, Yogyakarta.

Respati, E., L. Hasanah, S. Wahyuningsih, Sehusman, M. Manurung, Y. Supriyati, \& Rinawati. 2013. Buletin Konsumsi Pangan. Pusat data dan Sistem Informasi Pertanian 4: 1-56.

Roh, J. Yul, Y.J. Choi, M.S. Li, B.R. Jin, \& Y.H. Je. 2007. Bacillus thuringiensis as a Specific, Safe, and Effective Tool for Insect Pest Control. Journal Microbiology Biotechnology 17: 547-559.

Ruut, A.,A. Bravo, \& N. Crickmore. 2001. How Bacillus thuringiensis Has Evolved Specific Toxins to Colonize The Insect World. Review. Trends in Genetics 17: 193-199.

Subiadi, Y.A. Trisyono, \& E. Martono. 2014. Aras Kerusakan Ekonomi (AKE) larva Ostrinia furnacalis (Lepidoptera: Crambidae) pada Tiga Fase Pertumbuhan Tanaman Jagung. Jurnal Entomologi Indonesia 11: 19-26.

Tampubulon, D.Y., Y. Pangestiningsih, F. Zahara, \& F. Manik. 2013. Uji Patogenisitas Bacillus thuringiensis dan Metarhizium anisopliae terhadap Mortalitas Spodoptera litura Fabr. (Lepidoptera: Noctuidae) Di Laboratorium. Jurnal Online Agroekoteknologi 1: 783-793.

Triyani, F.M. 2015. Pengaruh Konsentrasi Subletal Toksin Bacillus thuringiensis terhadap Keperidian Ostrinia furnacalis. Skripsi. Universitas Gadjah Mada, Yogyakarta. 
Attachment 1. The mortality test of Spodoptera litura larvae on 3 and 7 DAT with Bacillus thuringiensis toxin Cry1A.105 and Cry2Ab2

\begin{tabular}{lcccc}
\hline Toxin & Concentration $(\mathrm{ppm})$ & No. larvae & \multicolumn{2}{c}{ Mortality $(\%) \pm$ SD } \\
\cline { 3 - 5 } & & & 3 DAT & 7 DAT \\
\hline Cry1A.105 & 48 & 30 & $16 \pm 0.89$ & $36 \pm 0.71$ \\
& 0.593 & 30 & $18 \pm 0.44$ & $28 \pm 1.15$ \\
& 0.198 & 30 & $12 \pm 0.44$ & $13 \pm 0.50$ \\
& 0.002 & 30 & $4 \pm 0.58$ & $14 \pm 0$ \\
Cry2Ab2 & 0 & 30 & $18 \pm 0.55$ & $4 \pm 0$ \\
& 15.5 & 30 & $2 \pm 0.45$ & $52 \pm 0.84$ \\
& 0.191 & 30 & $14 \pm 1.14$ & $28 \pm 0.84$ \\
& 0.064 & 30 & $18 \pm 0.45$ & $36 \pm 0.89$ \\
& 0.0008 & 30 & $0 \pm 0$ & $46 \pm 0.89$ \\
\hline
\end{tabular}

DAT (Day after treatment) 